\title{
The Multidisciplinary Nature Of Supply Chain Management: Where Does It Fit In Business Education?
}

Michael A. Jones, Southeastern Louisiana University, USA Robert Cope, Southeastern Louisiana University, USA

Michael C. Budden, Southeastern Louisiana University, USA

\begin{abstract}
Supply chain management is an area of growing interest in both industry and academics. A number of new text books are available for courses in the area, and a number of Colleges of Business are adding relevant curriculum. However, questions arise as to what Supply Chain Management comprises, as to needed courses in the area, and an appropriate delineation as to which department is best suited to offer such a program. Issues business educators will face in an effort to initiate supply chain management programs are discussed.
\end{abstract}

Keywords: Supply chain, management, education, discipline

\section{INTRODUCTION}<smiles>[CaH]</smiles>

upply chain management (SCM) has emerged as an important activity among business organizations. At least one expert views Wal-Mart's approach to logistics in retail as a more significant innovation than the invention of the transistor (Webster 2008). As is often the case with innovation and change in business organizations, the academic world is playing "catch-up" by offering curricula in supply chain management. Because supply chain management is a "hybrid" field of study which crosses the boundaries of traditional business disciplines, academicians from different areas have been drawn into the SCM arena: not an uncommon occurrence in the development of "new" disciplines. Textbooks in the fields of purchasing, logistics and operations are increasingly using the term "Supply Chain Management" in titles. The same is true of course titles, department names, and faculty titles. Because of the recent emergence of this hybrid field, one could wonder what attributes comprise the necessary components to be designated a "Professor of Supply Chain Management."

A corresponding issue appears to be where courses in SCM would best fit in business school curricula, or, which specifically which department would best manage such a program. Some institutions such as Arizona State have a department of SCM. But, a conventional departmental organization for business schools in the late $20^{\text {th }}$ century: Accounting, Finance, Management, Marketing, Economics and MIS, presents a conundrum as to the best location for a SCM program. Being the hybrid that it is, supply-chain management may not fit completely into any of these specific departments, which presents a dilemma. Supply chain management in application is cross functional, processed-based and is a boundary-spanning activity (Bowersox et. al 2007).

This paper examines issues associated with the emergence of supply chain management in business education. The problem of defining supply chain management is explored. The article provides recent salary information for professionals in the area of supply management and is intended to stimulate thought and discussion regarding the emergence of this field of business education. 


\section{BACKGROUND}

Marketing scholars have long concerned themselves with distribution and marketing channels. Early marketing textbooks contained more content relating to distribution than areas like consumer behavior or marketing research. In 1923, as part of the Alexander Hamilton Institute's Modern Business text series, Volume 5, by Butler, was entitled Marketing and Merchandising. Butler's text (1923) contains chapters on Channels of Distribution, Jobbers, Special Distributing Factors, Cooperative Buying Groups, Agencies, and Distribution and Dealer Cooperation. Interestingly, the supply-chain management concept appears quite similar to the vertical marketing system concept which has been in marketing text books for 40 years (Boone \& Kurtz 2001). A Principles of Marketing text published in 1957 by three faculty members at Ohio State University contains 6 chapters on the retailing system, 6 chapters on wholesaling, one on transportation, one on storage and warehousing, and one on distribution policies (Beckman et al 1957). Approximately one-half addresses topics that now fall under the umbrella of "supply chain management." Many marketing departments of US higher education institutions are named the "department of marketing and transportation."

In recent years however, of the four components of the marketing mix, place or distribution seems to be the "stepchild" of marketing education. Distribution and channels are commonly acknowledged as areas that are not addressed as much as areas such as promotion. It surprises few professors that consumer behavior, personal selling, advertising and marketing research get offered and taken by students more often than courses in the area of channels of distribution, transportation, logistics or purchasing management. It is interesting to note that in the job market there are more jobs available in the supply chain area at higher salaries than in advertising. Walmart announced last year that it would need 6,000 new managers in its logistics division. In fact, an examination of the business curricula of 26 colleges and universities in Louisiana, no public institution offered a degree program in the supply chain management area (transportation, logistics or purchasing management). Few offered sufficient coursework in the area to even offer students an emphasis or concentration in the area.

However, supply chain management has received attention from industry in recent years. So significant have the changes in distribution been that the area is commonly referred to as the "supply chain revolution" (Bowersox et. al 2007, Burt et. al. 2005)) It is commonly acknowledged that the single most important factor separating Wal-Mart from other retailers is the organization's ability to management its supply chain. The SCM concept is pervasive in manufacturing as well (Kahn 2004). As manufacturers have outsourced and become global, logistics has assumed a more important role (Dean 2005).In the next 10 years, US railroads will invest more in new rail lines than they did in the last 100 years (Machalaba 2008). Panama is expanding its canal to handle larger ships from Asia. The container traffic coming through Louisiana ports on the Gulf of Mexico is expected to triple by 2013 according to the Port of New Orleans.

Increased energy costs have caused even more management attention to become focused on the supply chain, leading to substantial investments and innovation. As a major consumer of gasoline, the United States Postal Service has ongoing a variety of initiatives to increase efficiencies and reduce fuel costs (Schmid 2008). Similarly, United Parcel Service has invested countless dollars to improve its efficiencies, including a relatively simple finding that by making right-hand turns, substantial savings can be realized through the elimination of wait times for turning across traffic (International Herald Tribune 2007).

\section{DEFINITION AND FIT}

The term supply chain management may have first appeared in a 1982 Financial Times article (Webster 2008). Several traditional areas of business education are now incorporating the term supply chain management: purchasing, logistics and operations. The term is also used in engineering courses and information systems courses addressing such issues as Enterprise Resource Planning (ERP). Here are examples: Wisner, Tan and Leong, in their new edition of an operations management book have used the title Principles of Supply Chain Management. In the $2^{\text {nd }}$ edition of their logistics text, Bowersox, Closs and Cooper (2007) use the title Supply Chain Logistics Management. An established purchasing management textbook by Burt, Dabbler and Starling is entitled "World Class Supply Management." Professional associations have joined the supply-chain name game. The oldest and largest professional association for buyers, the National Association of Purchasing Managers became the Institute of 
Supply Management 7 years ago. The Council on Logistics Management, a major professional organization is now the Council for Supply Chain Management Professionals. The answer then, as to what the area of supply chain management entails depends on whom one asks.

A challenge seems to arise when a business school considers a supply chain emphasis area, concentration or major. Should the program be offered under marketing, management, logistics or operations? What educational level or backgrounds should the instructors teaching the course have? Purchasing courses have often been taught by marketing faculty trained in organizational buying or the sales-purchasing interface. Logistics, which emerged from transportation, is often seen as a part of the marketing curricula. Other areas of supply chain management such as inventory, quality control, information systems, network integration, operational integration and manufacturing are topics from operations management. Figure 1 demonstrates the overlap of traditional business areas into what is supply chain management.

If defined broadly enough, SCM includes all functional areas of business and several areas from outside of business. Consider that a supply chain may be described as a business entity in which two or more organizations are linked by a flow of goods, funds, and information and may be global in scope. This could include everything from the raw materials used in manufacturing to the delivery of the product to the final consumer, and all activities in between. It not only includes organizations, but also their suppliers, buyers, vendors, customers, and others with whom it interacts. The general supply chain model in Figure 1 includes all business functions. The definition above emphasizes cross-functional links and seeks to manage those links to enhance a company's competitive advantage.

Figure 1: Core Disciplines Of Supply Chain Management

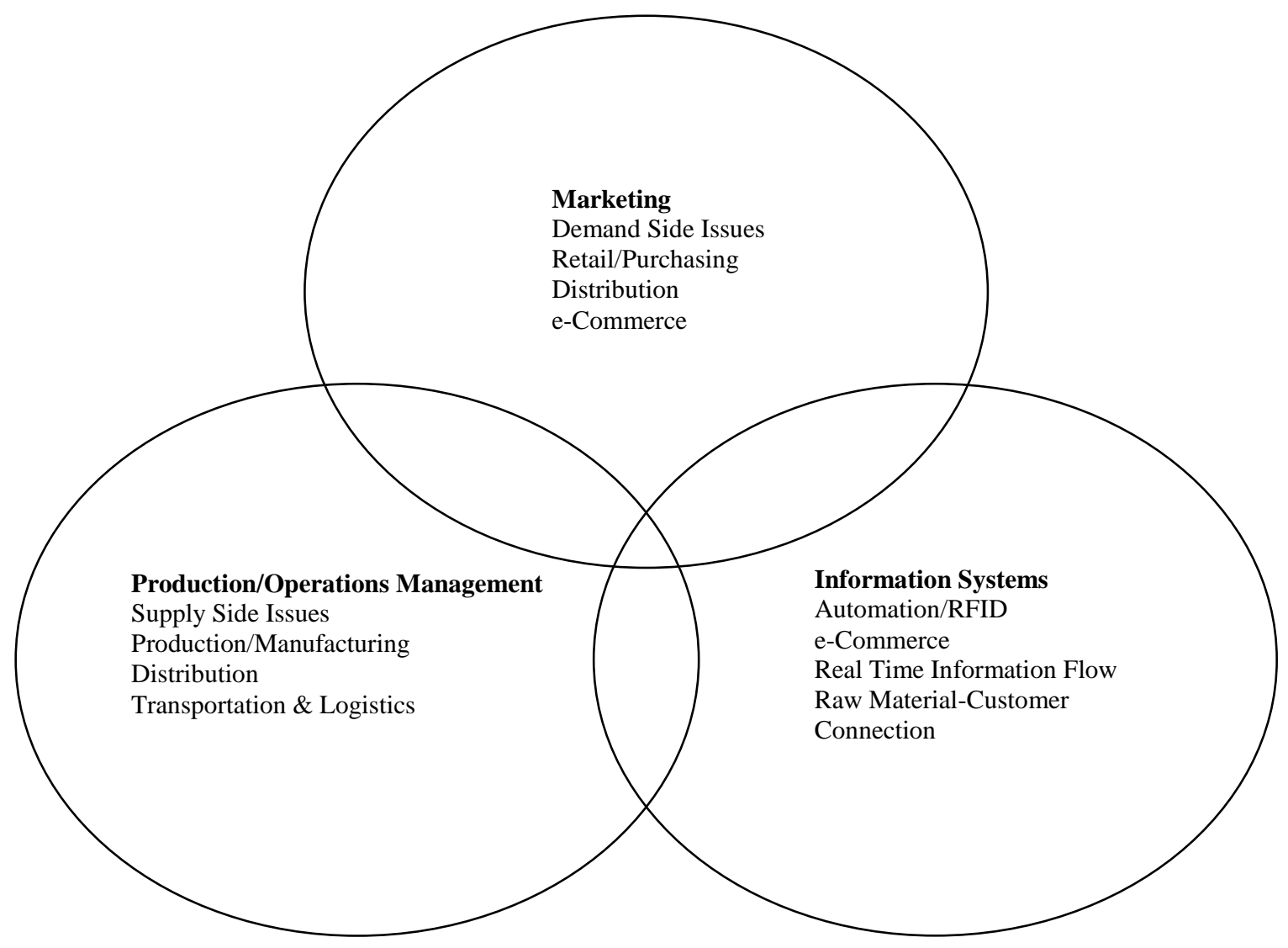


Yakhou and Dorweiler (2007) espouse the necessity of understanding and integrating inputs from different areas in order to manage today's corporations. SCM activities include forecasting, resource allocation, production planning, flow and process management, inventory management, customer delivery, after-sales support and service, and a host of other activities and processes familiar and basic to business. The multidisciplinary nature of SCM is pervasive. It is important to the success of SCM programs that traditional departmental "silos" be relegated to history, as cross-departmental cooperation is a must for a program to achieve a level of quality befitting the expectations of those who buy into the program. Indeed, an organizational structure based on customer departmentalization has the advantage of focusing on customer needs rather than the product or business functions (Williams, p. 399, 2003).

\section{Definitions from Texts That Emerged From the Purchasing Arena}

These definitions of supply chain management are from texts which emerged from purchasing management. In the $13^{\text {th }}$ edition of Purchasing and Supply Management, Lenders, Johnson, Flynn and Fearon (2006) provide the following definition:

The integration of related functions to provide effective and efficient materials and services to the organization (Lenders et. al 2006).

Burt, Dabbler and Starling (2003) are more philosophical in their definition provided in World Class Supply Management:

The world class supply management philosophy reflects those actions and values responsible for the continuous improvement of the design, development and management processes of an organization's supply system, with objectives of improving its profitability and ensuring its survival....it spans functional boundaries and company borders.

Another popular purchasing based text by Monczka, Handfield, Giunipero, and Patterson 2009), entitled Purchasing and Supply Management offers the following definition:

Supply management is the process of identifying, evaluating, selecting, and managing and developing suppliers to realize supply chain performance that is better than that of competitors.

Lastly among the texts which emerged from the purchasing area, Fawcett, Ellram and Ogden's (2007) provide the following definition in their text entitled Supply Chain Management: From Vision To Improvement:

Supply chain management is the design and management of seamless, value-added processes across organizational boundaries to meet the real needs of the end customer.

This last definition is also the definition adopted by the Institute of Supply Management (formerly the National Association of Purchasing Managers); the largest and oldest professional association in the area.

\section{Definitions From Logistics}

The major professional organization in the area of logistics is The Council of Logistics Management. Formerly the Council of Supply Chain Professionals, it changed its name approximately two years ago to reflect current realities. That organization uses the following broad and encompassing definition of SCM:

The planning and management of all activities involved in sourcing and procurement, conversion, and all logistics management activities. It also included the coordination and collaboration with channel partners, which can suppliers, intermediaries, third party service providers, and customers (www.cscmp.org).

Bowersox, Closs and Cooper (2007) in Supply Chain Logistics Management posit: 
SCM consists of firms collaborating to leverage strategic positioning and to improve operating efficiency.

Harrison and van Hoek (2008) in Logistics Management conclude that SCM "thus appears as the end-toend management of the network as a whole, and of the relationships between the various lengths." In another logistics text by Murphy and Wood (2008), the authors do not even define or mention the phrase supply chain management in chapter 1, but use a traditional definition of logistics (Murphy and Wood 2008).

\section{Definitions From The Operations Perspective}

Authors in the Operations area have also weighed in on the discussion. In Operations and Supply Management by Jacobs and Chase (2008), the authors define both terms in one definition:

Operations and supply management is defined as the design, operation, and improvement of the systems that create and deliver the firm's primary products and services.

Another operations based text by Webster (2008) Supply Chain Management posits the following:

SCM involves the management of activities surrounding the flow of raw materials to the finished product or service enjoyed by end customers and back in the case of recycling or return.

Wisner, Leong and Tan (2009) offer no less than three definitions: the one above from the Institute of Supply Management, another from the Supply Chain Council, and a third from a logistics based group The Council of Supply Chain Management Professionals. It can be concluded that if one refers to university text books on SCM for a definition of the field, one gets a variety of definitions.

\section{SUPPLY CHAIN MANAGEMENT PROGRAMS}

As is often the case, medium and smaller institutions are following the lead of the larger schools in establishing such programs. There are several ongoing projects to create such programs at regional, public institutions. Southeastern Louisiana University just received permission from the state Board for its proposed Supply Chain Management degree program. It will be the first bachelor's degree program in supply chain management in the state. The need for the program is well-documented and supported by local and regional transportation firms.

\section{THE SALARY SITUATION}

Each year the Institute of Supply Management (formerly NAPM) conducts a salary survey of members. ISM members primarily work in the purchasing or sourcing arena. According to ISM's 2008 Salary Survey, based on 2007 salaries and benefits, the average salary for a supply management professional for 2007 rose to $\$ 92,165$, an increase of 4.3 percent from the average of $\$ 88,380$ reported in 2006 (Schultz 2008). This indicates a positive trend for supply management professionals, as these numbers continue to increase from the $\$ 78,470$ reported in ISM's first salary survey published in 2006. An increasing number of supply management professionals are earning salaries, including bonuses, exceeding $\$ 100,000$. In all, 31 percent of respondents reported earning a six-figure salary, up from 28 percent one year ago. The high salary was reported as $\$ 520,000$, and the low salary was reported as $\$ 25,000$. The median salary was $\$ 80,000$. The average salary by position is displayed below.

Position

Chief Sourcing/Purchasing Officer

VP Purchasing/SM/Sourcing

Director of Purchasing/SM/Sourcing

Manager of Purchasing/SM/Sourcing

$3+$ Years Experience Staff

Entry level $(<3$ years experience
Average 2007 Salary

$\$ 140,265$

$\$ 206,260$

$\$ 128,600$

$\$ 94,900$

$\$ 70,000$

$\$ 52,353$ 
The average salary of employees with a bachelor's degree was reported to be $\$ 95,165$, Master's degree $\$ 119,037$ and doctorates, $\$ 153,400$.

\section{RECOMMENDED STEPS IN CREATING A SCM PROGRAM}

Providing SCM programs to serve the needs of students and industry alike requires substantial effort. While the actual steps to create a program may vary from university to university, most will require the following.

- $\quad$ Determine the need / environmental scanning

- $\quad$ Get necessary faculty and college administrators on-board

- $\quad$ Develop an advisory board / develop industry linkages

- $\quad$ Create faculty linkages

- $\quad$ Develop course work if needed

- $\quad$ Develop and submit letter of intent / proposal to appropriate committees/boards

- Implement program

Environmental scanning which may take the guise of student and industry needs surveys will help drive the program's development. If industry in the region is growing and the need for supply chain management programs becomes apparent, convincing others of the need for a new program will be simplified. No need, no need for a program. If there is a need, program development will be simplified.

It will be necessary to get necessary faculty and administrators on-board and in favor of seeing the program created. The necessary faculty will likely be those directly involved in the core coursework and efforts to drive the program through to completion. The head of the department that is likely to manage the program (eg., Marketing department head) and the dean of the college need to be supportive if the program is to have a chance to succeed. At this point, it is assumed that at least one program "champion" has taken the lead in driving the program. This champion does not have to be an administrator, but rather has to be someone who is strongly committed to the program's creation and success.

An effective advisory board is absolutely essential if the program is to be effective. Advisory board members from industry can serve in course development and design. Members of the board will hopefully provide support. And most importantly, members of the advisory board can serve as advocates for the program to governing boards and others. The advisory board should be constituted early on in the program's development to fully glean its value. These will be among those who will benefit directly from the final product of the program so their participation and input is vital.

As stated before, Supply Chain Management is an inter-disciplinary field. Creating linkages with and gaining the support of faculty in related disciplines is vital to program success. Faculty from management, operations management, and statistics need to be kept up to date and involved in the program's development. Their insight will drive much of the program's success.

Once faculty members who will be involved are identified, they should be relied on to develop new coursework that may be needed. They should do this with input from the advisory board members. They should follow all regulations and processes in place that are required to create new courses.

As if all of this wasn't enough, most universities have a multi-step procedure for creating new programs. Typically, the process involves developing a letter of intent that demonstrates need and relevance, demonstrates resource availability and/or cost effectiveness, demonstrates industry support, provides appropriate curricula design, and has effective administrative and faculty governance procedures in place to assure continued success. All of these are provided for if the steps mentioned above are followed.

Finally, given that the program is approved, it needs to be implemented. Career opportunities abound in the field. Successful students will find they are in demand and that salaries are strong. Industry that benefits from 
the program will be appreciative. The university and college will benefit. Supply chain management holds much promise - especially as fuel and transportation costs increase.

\section{SUMMARY AND RECOMMENDATIONS}

It is recommended to colleges of business that have not yet initiated a curriculum in SCM that they consider offering such a program. As with any new program, cost considerations and local market needs may dictate the reality for any one institution. However, the probability that many relevant courses are already being offered in many schools is high. Operations management, retail management, purchasing, logistics, statistics, and transportation are often found in many curricula. Thus, existing faculty may be called upon to initiate a SCM program.

A challenge might be attracting faculty members to teach new courses that may be needed. Operations management faculty might be more willing to teach in the area of logistics, as most operations texts have a chapter in purchasing and one or more in logistics or transportation. Concentrations or emphasis areas can be added at relatively low cost, which gives students an opportunity to show an employer some level of interest and knowledge in the field. So even if a major degree program in SCM may prove out of reach, a concentration that serves the needs of the industry and students may be relatively easy to implement. Indeed, as Harbrecht, Neidermeyer, and Tuten (2006) proffer, successful education prepares students for the needs of the business environment.

A final recommendation in creating a SCM program is to involve local SCM organizations and their managers from the beginning. Many are eager to support and encourage such programs. At the authors' college, a regional transportation organization has given significant funding in support of its program to purchase equipment, provide internships and scholarships and provide faculty development activities. These activities have all been a result of the desire of local transportation and supply chain management professionals to further their firms' interests through the education and development of future SCM professionals.

The Institute of Supply Management (www.ism.ws) is the world's oldest and largest professional association in the purchasing area. The organization places a priority on professional education. One opportunity that many faculty may be unaware is that the ISM allows faculty members who teach in the area to join the ISM for free. Most cities have affiliates which have monthly meetings, which foster an industry interface for area institutions and their faculty. So the final question is - when are you going to get started?

\section{AUTHOR INFORMATION}

Dr. Michael Jones is an Associate Professor of Marketing at Southeastern Louisiana University. He directs the Supply Chain Management initiative at Southeastern. Dr. Jones's research interests lie in supply chain management, purchasing, association management, and customer service.

Dr. Robert Cope is Interim Department Head of the Department of Marketing and Finance at Southeastern Louisiana University. Dr. Cope's research interests are in the areas of electric utility management and productivity, quality improvement and business education.

Dr. Michael Budden is the Mayfield Professor of Marketing at Southeastern Louisiana University. Dr. Budden's research interests involve business ethics, marketing law, retailing and business education.

\section{REFERENCES}

1. Beckman, T.N., Maynard, N.M. and Davidson, W.R. (1957). Principles of Marketing, $6^{\text {th }}$ Ed., The Ronald Press Co, New York.

2. Boone, L.E. and Kurtz, D.L. (2001). Contemporary Marketing $10^{\text {th }}$ Ed., Southwestern, Mason, Ohio. Pg. 403.

3. Bowersox, D.J., Closs, D.J. and Cooper, M.B. (2007). Supply Chain Logistics Management $2^{\text {nd }}$, McGrawHill Irwin, Boston 
4. Burt, N. D., Dobler, W.D. and Starling, S.L. (2003). World Class Supply Management, McGraw Hill Irwin, Boston. Pg. 2.

5. Butler, R. S.. (1923). Marketing and Merchandising, Vol. 5 of the Modern Business Series, Alexander Hamilton Institute.

6. Dean, J. and Tam P.W. (June 2005). The Laptop Trail; The Modern PC Is a Model Of Hyperefficient Production And Geopolitical Sensitivities, in The Wall Street Journal. (Eastern edition). New York, N.Y.: Jun 9, 2005. pg. B.1

7. Fawcett, S.E., Ellram, L.M. and Ogden, J.A. (2007). Supply Chain Management, Pearson Prentice Hall, Upper Saddle River, N.J.

8. Harbrecht, A., Neidermeyer, P. E. and Tuten, T. L. (2006).Changes in Higher Education: How to Address the Learning Needs of the Latino Population," in Journal of College Teaching and Learning, Vol. 3, Number 10, pg. 63-69.

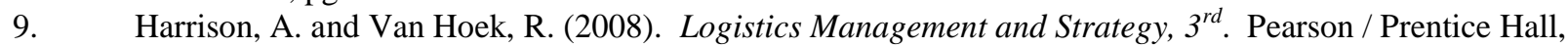
Harlow, England.

10. International Herald Tribune, (August 6, 2007). United Parcel Service's 100-year Anniversary Approaches as Company Eyes Future Growth, (www.iht.com/bin/print/php?id=7011328, printed 8/19/2008.

11. Jacobs, R. R. and Chase, R. B. (2008). Operations and Supply Management: The Core, McGraw-Hill / Irwin, Boston, MA.

12. Kahn, G (August 2004). Making Labels for Less; Supply-Chain City Transforms Far-Flung Apparel Industry; Help for 'the Button Guy,' in The Wall Street Journal. (Eastern edition). New York, N.Y.pg. B.1

13. Lenders, M.R., Johnson, P.F., Flynn, A.E. and Fearon, H.E. (2006). Purchasing and Supply Management $13^{\text {th }}$ Ed., McGraw-Hill Irwin, Boston.

14. Machalaba, D (February 2008). New Era Dawns for Rail Building; Lines Add Tracks, Upgrade Tunnels To Take On Trucks, in The Wall Street Journal. (Eastern edition). New York, N.Y.pg. A.1

15. Monczka, R. M, Handfield, R. B., Giunepero, L.C., and Patterson, J.L., (2009) Purchasing and Supply Management $4^{\text {th }}$ Ed., SouthWestern / Cingage, Mason, Ohio.

16. Murphy, P. L. and Wood, F. D. (2009). Contemporary Logistics, $9^{\text {th }}$, Pearson / Prentice Hall, Upper Saddle River, NJ.

17. Schmid, R. E. (June 15, 2008). Petrol Prices Pinching Post Office, Foxnews.Com www.foxnews.com/wires/2008Jun15/0,4675,PostalPetrol,00.html..

18. Schultz, D (May 2008). 2008 Salary Survey, Inside Supply Management, Published By the Institute of Supply Management, Tempe, Az. pp 24-28. www.ism.ws.

19. Webster, S (2008). Principles of Supply Chain Management, McGraw-Hill Irwin, Boston pg. 7.

20. Williams, Chuck (2003). Management $2^{\text {nd }}$. Thomson-Southwestern, Mason, Ohio.

21. Wisner, J.D., Leong, G.K. and Tan, K.C. (2009). Principles of Supply Chain Management $2^{\text {nd }}$, Southwestern (Cingage), Mason, Ohio.

22. Yakhou, M. and Dorweiler, V. P. (Second Quarter 2007). Fostering Cross-Functional Skills and Attitues in Business Administration Students, in College Teaching Methods and Styles Journal, Volume 3, Number 2, pg. 49-57. 